\title{
Invasive lumbricid earthworms of Kamchatka (Oligochaeta)
}

\author{
Sergei V Shekhovtsov ${ }^{1 *}$, Elena V Golovanova ${ }^{2}$ and Sergei E Peltek ${ }^{1}$
}

\begin{abstract}
Background: Invasive earthworms often have huge ecological impact, especially when they colonize previously earthworm-free zones. Kamchatka is a remote and weakly populated region whose invertebrate fauna is insufficiently studied. We investigated earthworm diversity in several natural and anthropogenic habitats of Kamchatka by morphological analysis and barcoding using the mitochondrial cox 1 gene.

Results: We added four new species (Dendrobaena octaedra, Dendrobaena attemsi, Lumbricus rubellus, and Aporrectodea caliginosa) and one subspecies (Dendrodrilus rubidus subrubicundus) to the four earthworm species known previously from this region. Moreover, this is the first report of Dendrobaena attemsi in Asia. We found one mtDNA haplotype for each Eisenia fetida, Dendrodrilus rubidus subrubicundus, and Dendrodrilus rubidus tenuis; two significantly diverged haplotypes for Dendrobaena octaedra and A. caliginosa; and three for L. rubellus. In addition, cox 1 sequences of Eisenia nordenskioldi nordenskioldi, the only earthworm species that could be of native origin, were identical to those of Eisenia nordenskioldi pallida from Khakassia and Tuva.

Conclusions: Molecular genetic analysis demonstrated that all earthworms found by us are of invasive origin, and for some of them, there were most probably several independent introduction events. This turned out to be true even for E. nordenskioldi, the species that was earlier considered to be native to this region. Our results suggest it might be possible that the whole earthworm fauna of Kamchatka is of invasive origin, which makes it a good model for studying the effects of earthworm invasions into previously earthworm-free regions.
\end{abstract}

Keywords: Earthworms; Lumbricidae; Kamchatka; cox1

\section{Background}

Earthworms are one of the most important invasive animals, at least in terms of biomass and the number of individuals (Michaelsen 1903; Gates 1972, 1982; Lee 1985, Blakemore 2009, 2012a, b; James 2011). Invasive earthworms continue their expansion into previously earthworm-free zones (Tiunov et al. 2006), where they often have huge ecological impact (Bohlen et al. 2004; Frelich et al. 2006). In this connection, they are a major concern in some regions that were until recently devoid of earthworms. For example, it is believed that in large parts of the northern part of North America, native earthworms were eliminated by Pleistocene glaciations. While recolonization of these regions started long ago, massive invasions by European earthworms began in

\footnotetext{
* Correspondence: shekhovtsov@bionet.nsc.ru

${ }^{1}$ Laboratory of Molecular Biotechnology, Institute of Cytology and Genetics SB RAS, Novosibirsk 630099, Russia

Full list of author information is available at the end of the article
}

many places only a few decades ago, often with a dramatic impact (Gates 1982; Scheu and Parkinson 1994; Cameron et al. 2008).

The Kamchatka peninsula is a geographically remote and sparsely populated region. Much of Kamchatka is covered by forests dominated by stone birch or conifers, but its forests are separated from the mainland boreal zone by a vast stretch of tundra. Species diversity of Kamchatka was significantly reduced by Pleistocene glaciations, but refugia are believed to have existed during this period, although their extent is still unclear (Egorova 2008).

There are few studies on earthworms of Kamchatka. Currently, only four earthworm species are known for this region. Michaelsen (1929) and Sokolskaya (1972, 1983) found Eisenia nordenskioldi (Eisen 1879) on the banks of thermal springs. Sokolskaya (1983) reported on cosmopolitan earthworm species Bimastos parvus (Eisen 1874) (referred to in Russian literature as Allolobophora

\section{实}


parva Eisen 1874) and Dendrodrilus rubidus tenuis (Eisen 1874) on river banks. A report on Eisenia fetida (Savigny 1826) in Petropavlovsk-Kamchatsky is mentioned by Vsevolodova-Perel (1997).

Therefore, all earthworm species from Kamchatka are cosmopolitan species, except for E. nordenskioldi, which is a Siberian species that is also found in Eastern Europe. Kamchatka has a rather harsh climate, so agriculture is very limited there; the number of human-mediated dispersal events should have been low, and natural colonization of Kamchatka by earthworms from the mainland is now impossible. Almost all traffic from the mainland comes by sea or, less significantly, by air. Therefore, Kamchatka is a good model for studying the capabilities of earthworms to invade and colonize boreal regions.

We collected a sample of earthworms from several anthropogenic and natural locations in Kamchatka, performed morphological identification, and obtained sequences of the mitochondrial $\operatorname{cox} 1$ gene. The aim of our study was to investigate the earthworm fauna of Kamchatka and to attempt to trace its origin.

\section{Methods}

Earthworms were collected in several locations in Kamchatka (Table 1). Morphological identification was performed according to Vsevolodova-Perel (1997). Earthworm individuals used in this study are stored in the Institute of Cytology and Genetics, Novosibirsk.

The total DNA was extracted from several caudal segments using the BioSilica DNA extraction kit according to manufacturer's instructions (BioSilica Inc., Novosibirsk, Russia). A fragment of the mitochondrial $\operatorname{cox} 1$ gene was amplified using the universal primers LCO1490m (5'-TACTC-AACAA-ATCACAAAGA-TATTG-G-3'; modified from Folmer et al. 1994) and COI-E- (5' -TATACTTCTG-GGTGT-CCGAAGAATC-A-3'; Bely and Wray 2004). PCR reaction mixture contained $1.5 \mathrm{mM} \mathrm{MgCl}_{2}$,
$65 \mathrm{mM}$ Tris- $\mathrm{HCl}\left(\mathrm{pH}\right.$ 8.8), $16 \mathrm{mM}\left(\mathrm{NH}_{4}\right)_{2} \mathrm{SO}_{4}, 0.05 \%$ Tween-20, $0.2 \mathrm{mM}$ of each dNTP, $0.3 \mathrm{mM}$ primers, and $1 \mathrm{U}$ of recombinant Taq polymerase (SibEnzyme, Novosibirsk, Russia). All sequences obtained in this study were deposited in GenBank under accession nos. KJ772496-KJ772504, JX531568, JX531571, KF471787KF471792, and KF471831-KF471842 (Table 1). When several individuals had identical $\operatorname{cox} 1$ sequences, only one sequence was submitted, except for Aporrectodea caliginosa.

\section{Results}

According to morphological analysis, the earthworms collected by us belonged to the species $A$. caliginosa (Savigny, 1826), Lumbricus rubellus (Hoffmeister, 1843), Dendrobaena octaedra (Savigny, 1826), and Dendrobaena attemsi (Michaelsen 1903) as described by Rota and Erséus (1997) and Blakemore (2012b); Dendrodrilus rubidus tenuis, Dendrodrilus rubidus subrubicundus (Eisen, 1874), E. nordenskioldi, and E. fetida; in addition, some specimens could not be reliably identified (Table 1). Therefore, our study adds three new species (Dendrobaena octaedra, Dendrobaena attemsi, L. rubellus, and A. caliginosa) and one subspecies (Dendrodrilus rubidus subrubicundus) to the four earthworm species and subspecies that were earlier reported for Kamchatka.

We obtained 61 cox 1 sequences. Molecular analysis confirmed the morphological diagnosis in all cases.

Several diverse earthworm species were found in the Paratunka town, in a compost heap near the greenhouses of the Institute of Volcanology. The location suggests that diverse biological material, including plant and soil samples, is often delivered there. $\operatorname{cox} 1$ sequences of two individuals of E. fetida from Paratunka were identical to those of the specimens from Denmark (GenBank accessions FJ214216 and FJ214217), France (GU013880 and GU013881), and also to three specimens of $E$.

Table 1 Earthworms collected in this study

\begin{tabular}{|c|c|c|c|c|}
\hline Location & Species & $N$ & $n$ & GenBank accession number \\
\hline \multirow{2}{*}{$\begin{array}{l}\text { Near Krutoberegovo village, creek bank in a small valley } \\
\text { among two hills }\end{array}$} & Aporrectodea caliginosa & 18 & 2 & KF471787-92 and KF471831-KF471842 \\
\hline & Lumbricus rubellus & 3 & 2 & E0384 and E0387 \\
\hline \multirow[t]{4}{*}{ Near Paratunka town, a compost heap near greenhouses } & Eisenia fetida & 2 & 1 & JX531571 \\
\hline & L. rubellus & 2 & 2 & E0182 and E0180 \\
\hline & Dendrodrilus rubidus subrubicundus & 1 & 1 & JX531568 \\
\hline & Dendrobaena attemsi & 2 & 1 & E0179 \\
\hline \multirow[t]{3}{*}{ Stone birch forest A, $150 \mathrm{~km}$ north of Petropavlovsk-Kamchatsky } & E. nordenskioldi & 2 & 1 & E1359 \\
\hline & Dendrobaena octaedra & 8 & 1 & E0351 \\
\hline & Dendrodrilus rubidus tenuis & 9 & 1 & E0349 \\
\hline Stone birch forest B, $150 \mathrm{~km}$ north of Petropavlovsk-Kamchatsky & Dendrobaena octaedra & 14 & 1 & E1121 \\
\hline Total & & 61 & 13 & \\
\hline
\end{tabular}

$N$, number of individuals; $n$, number of unique $\operatorname{cox} 1$ haplotypes. 
fetida (AY874517, AY874516, and AY874515) from the study of Pérez-Losada et al. (2005) (could be Spain or Ireland). The molecular problems with several previous studies of taxonomic components of the A. caliginosa, $E$. fetida, and E. nordenskioldi species complexes were commented on by Blakemore et al. (2010) and by Blakemore (2013). One of the individuals was identified as Dendrodrilus rubidus subrubicundus; its cox 1 sequence differed from that of Dendrodrilus rubidus from Europe (DQ092900) by eight substitutions.

Two earthworms from Paratunka were morphologically identified as Dendrobaena attemsi. Some morphological characters, however, deviated from the diagnosis: pigmentation was low on the medial surface of the segments 8 to 11 , the head was almost tanylobic, and the ventral surface was thickened only on the 14th and the 15th segments. The identity of this species was confirmed by a closely related cox 1 barcode sequence (99\% sequence similarity) of this species from the south of Sweden in the BOLD database (Ratnasingham and Hebert 2007) and by two unpublished sequences kindly provided by Prof. R. Blakemore (courtesy of Dr Ramon Gallego of University of Auckland, New Zealand (see Blakemore 2012a)), which had only two nucleotide substitutions. No close matches (with more than $85 \%$ sequence similarity) to our sequence were found in GenBank. The only sequence of Dendrobaena attemsi from GenBank (FJ214224 from 'USA: Olympic National Forest, Washington') had low sequence similarity to our sequence and turned out to be close (1 substitution) to some sequences of Dendrobaena octaedra, and that individual was probably misidentified.

cox1 sequence of one L. rubellus individual from Paratunka differed from that of JN869918 from Europe by six substitutions. Another one found in the same location was identical to FJ214213 from Denmark; two worms from Krutoberegovo had the same haplotype. In addition, Krutoberegovo yielded another L. rubellus haplotype that was most closely related to JQ909123 from Ohio, USA, differing from it by seven nucleotide substitutions. Therefore, three significantly diverged $L$. rubellus haplotypes were found among only five $L$. rubellus individuals.

The site referred to as Krutoberegovo was located on a creek bank in a bottomland between the Krutoberegovo village and Petropavlovsk-Kamchatsky, about $100 \mathrm{~m}$ from the road and several hundred meters from the nearest village gardens. This site is infrequently visited by humans.

In addition to L. rubellus, 18 specimens of $A$. caliginosa were also found in Krutoberegovo. cox 1 sequences of all these individuals belonged to the mitochondrial lineage 3 of this species (Porco et al. 2012). Seventeen of them differed by one substitution from the accessions JQ908867 and JQ908830 from USA and JN869885 and JN869884 from Europe. The remaining single specimen differed from all known A. caliginosa sequences by at least 20 substitutions, which significantly exceeds the range of intralineage diversity, so that it might well represent a new lineage of $A$. caliginosa.

We also obtained epigeic earthworms from stone birch forest about $150 \mathrm{~km}$ to the north of PetropavlovskKamchatsky. Two locations (about $15 \mathrm{~km}$ apart) are represented by small valleys separated by mountain ridges with no vegetation and are occasionally visited by humans but never had any type of agriculture. Both locations contained Dendrobaena octaedra. Molecular analysis demonstrated that individuals from the two populations belonged to different genetic lineages. $\operatorname{cox} 1$ sequences from individuals of one of the locations differed by a single nucleotide substitution from Dendrobaena octaedra individuals from Austria (DQ092895), Canada (EU035484), and Europe (precise location unknown, JN869900), while those of the other one was most closely related to Dendrobaena octaedra from an unknown location (JN869900), differing from it by three substitutions.

One of the locations also harbored two additional earthworm species, Dendrodrilus rubidus tenuis and $E$. nordenskioldi nordenskioldi. cox 1 sequences of nine Dendrodrilus rubidus tenuis individuals were identical and differed from a sequence of this species from Denmark (FJ374776) by only two substitutions. Unexpectedly, two individuals identified as E. nordenskioldi nordenskioldi had sequences identical to that of $E$. nordenskioldi pallida (Malevich 1956) from Khakassia (JX531522 and JX531523) and Tuva (our data).

\section{Discussion}

Representatives of A. caliginosa, L. rubellus, E. fetida, and Dendrodrilus rubidus subrubicundus were found in anthropogenic habitats and are undoubtedly introduced species in Kamchatka. In natural habitats, we found three species, Dendrobaena octaedra, Dendrodrilus rubidus tenuis, and E. nordenskioldi nordenskioldi. Analysis of cox 1 sequences demonstrated that they were also of invasive origin. This corroborates the findings of Sokolskaya (1983) who also found invasive species (Dendrodrilus rubidus tenuis and B. parvus) in natural habitats. All of the species found by us are cosmopolites (Perel 1979; VsevolodovaPerel 1997; Tiunov et al. 2006). The only exception is $E$. nordenskioldi nordenskioldi, which is native to Siberia and was demonstrated to have persisted in some regions for millions of years (Shekhovtsov et al. 2013). However, molecular genetic analysis suggests that our sample of this species from Kamchatka was also introduced from the mainland.

Finding cox1 haplotypes of E. nordenskioldi pallida in our E. nordenskioldi nordenskioldi individuals was unexpected. While those two subspecies were once considered simply different pigmentation forms of the same 
species (Malevich 1956; Perel 1979), it was later discovered that they have different ploidy levels (E. nordenskioldi pallida is diploid and E. nordenskioldi nordenskioldi is polyploid) and have different ecological properties (Vsevolodova-Perel and Bulatova 2008; Blakemore 2013; Vsevolodova-Perel and Leirikh 2014). The worms we found were epigeic, while E. nordenskioldi pallida is known to be strictly endogeic. There is, however, an alternative viewpoint (D Berman, personal communication) that various degrees of pigmentation intensity (including its near absence) may be manifested in both subspecies. Our findings corroborate this viewpoint, suggesting that E. nordenskioldi pallida could have adapted to epigeic lifestyle, which resulted in changes in pigmentation.

It is generally suggested that biological invasions are usually characterized by considerable reduction of genetic diversity. For earthworms, however, this seems to be not the case: Porco et al. (2012) demonstrated that there is no decline in genetic diversity in several earthworm species in North America in comparison to source European populations. In contrast to Porco et al. (2012), we found low genetic diversity of invasive earthworms from Kamchatka. This may be explained by the fact that this region is weakly populated and, consequently, there could be much less dispersal events. Nevertheless, we found two significantly divergent $\operatorname{cox} 1$ haplotypes for Dendrobaena octaedra and A. caliginosa, and three for L. rubellus.

Among the factors that facilitate invasions in earthworms, frequent occurrence of parthenogenesis may be the factor that gives them the potential to rapidly colonize new regions (Gates 1972; Blakemore 2012a, b). However, there were more amphimictic earthworms in our sample (L. rubellus, E. fetida, E. nordenskioldi, A. caliginosa, and Dendrodrilus rubidus subrubicundus) than parthenogenetic ones (Dendrobaena octaedra and Dendrodrilus rubidus tenuis). Cold tolerance is another important factor: all invasive earthworms reported from Kamchatka are believed to have originated in warmer climates; however, they were nevertheless able to successfully colonize this peninsula that has rather harsh climate. Some of them (Dendrobaena octaedra, A. caliginosa, and both subspecies of E. nordenskioldi) are indeed characterized by high cold tolerance both as adult worms and cocoons (Berman et al. 2002; Berman and Meshcheryakova 2013; Meshcheryakova and Berman 2014). However, other species (Dendrodrilus rubidus tenuis and L. rubellus) are cold tolerant only at the cocoon stage, while adult worms die at $-1^{\circ} \mathrm{C}$ to $-3^{\circ} \mathrm{C}$ (Berman et al. 2010; Meshcheryakova and Berman 2014). This means that they have adapted to complete their developmental cycle in the short warm period. Finally, E. fetida has no cold resistance, as both adults and cocoons of this species die at $-1^{\circ} \mathrm{C}$ (Berman et al. 2009). However, it is evident that despite no cold tolerance, it is still capable of living in anthropogenic environment.

\section{Conclusions}

To conclude, our study added four new species and one subspecies to the four earthworm species known previously for Kamchatka. In addition, this is the first report from Asia for Dendrobaena attemsi (as confirmed by Blakemore (2012a) while recording it from New Zealand). Molecular genetic analysis allowed us to demonstrate that at least some earthworm species in Kamchatka are represented by several mitochondrial lineages, which most probably correspond to independent invasion events. Moreover, examination of several locations including sites without any traces of economic activity allows us to speculate that the whole earthworm fauna of Kamchatka might be of invasive origin, as the only species, E. nordenskioldi nordenskioldi, that could potentially be native to this region, was found to be of invasive origin.

\section{Competing interests}

The authors declare that they have no competing interests.

\section{Authors' contributions}

SS collected the material, carried out all molecular analysis and drafted the manuscript. EG performed morphological analysis. SP coordinated the study and helped draft the manuscript. All authors read and approved the final manuscript.

\section{Acknowledgements}

This study was supported by RFBR grant 14-04-01121_a. We are grateful to A. Bryanskaya for the earthworms from Paratunka and to O. Ignatenko for the technical assistance.

\section{Author details}

'Laboratory of Molecular Biotechnology, Institute of Cytology and Genetics SB RAS, Novosibirsk 630099, Russia. ²Omsk State Pedagogical University, Naberezhnaya Tukhachevskogo 14, Omsk 644099, Russia.

Received: 7 May 2014 Accepted: 24 July 2014

Published: 14 August 2014

\section{References}

Bely AE, Wray GA (2004) Molecular phylogeny of naidid worms (Annelida: Clitellata) based on cytochrome oxidase I. Mol Phylogenet Evol 30(1):50-63 Berman DI, Meshcheryakova EN (2013) Ranges and cold hardiness of two earthworm subspecies (Eisenia nordenskioldi, Lumbricidae, Oligochaeta). Biol Bull 40:719-727

Berman DI, Meshcheryakova EN, Alfimov AV, Leirikh AN (2002) Distribution of the earthworm Dendrobaena octaedra (Lumbricidae, Oligochaeta) in the northern Holarctic is restricted by its insufficient freeze tolerance. Zool Zhurnal 81:1210-1221

Berman DI, Leirikh AN, Mescheryakova EN (2009) Cold hardiness of ontogenetic phases of the muckworm Eisenia fetida (Oligochaeta, Lumbricidae). Zool Zhurnal 3:272-279

Berman DI, Meshcheryakova EN, Leirikh AN (2010) Egg cocoons of the earthworm Dendrodrilus rubidus tenuis (Lumbricidae, Oligochaeta) withstand the temperature of liquid nitrogen. Dokl Biol Sci 434:347-350

Blakemore RJ (2009) Cosmopolitan earthworms - a global and historical perspective. In: Shain DH (ed) Annelids in Modern Biology. Wiley-Blackwell, Hoboken, pp 257-283

Blakemore RJ (2012a) On Schmarda's lost worm and some newly found New Zealand species. J Species Res 1(2):105-132

Blakemore RJ (2012b) Cosmopolitan Earthworms: An Eco-Taxonomic Guide to the Peregrine Species of the World, Vththth edn. VermEcology, Yokohama 
Blakemore RJ (2013) Earthworms newly from Mongolia (Oligochaeta, Lumbricidae, Eisenia). ZooKeys 285:1-21

Blakemore RJ, Kupriyanova E, Grygier MJ (2010) Neotypification of Drawida hattamimizu Hatai, 1930 (Oligochaeta:Megadrili:Moniligastridae) and the first COl sequence from an earthworm type. Zookeys 41:1-29

Bohlen PJ, Groffman PM, Fahey TJ, Fisk MC, Suárez E, Pelletier D, Fahey R (2004) Ecosystem consequences of exotic earthworm invasion of north temperate forests. Ecosystems 7:1-12

Cameron EK, Bayne EM, Coltman DW (2008) Genetic structure of invasive earthworms Dendrobaena octaedra in the boreal forest of Alberta: insights into introduction mechanisms. Mol Ecol 17(5):1189-1197

Egorova IA (2008) An outline of the formation of modern vegetation of Kamchatka. In: Events and People: Proceedings of the XXV Krasheninnikov Readings. Ministry of Culture of the Kamchatka krai, Petropavlovsk-Kamchatsky

Folmer O, Black M, Hoeh W, Lutz R, Vrijenhoek R (1994) DNA primers for amplification of mitochondrial cytochrome c oxidase subunit I from diverse metazoan invertebrates. Molecular Mar Biol Biotech 3(5):294-299

Frelich LE, Hale CM, Scheu S, Holdsworth AR, Heneghan L, Bohlen PJ, Reich PB (2006) Earthworm invasion into previously earthworms-free temperate and boreal forests. Biol Inv 8:1235-1245

Gates GE (1972) Burmese earthworms-an introduction to the systematics and biology of megadrile oligochaetes with special reference to South-East Asia. Trans Am Philos Soc 62(7):1-326

Gates GE (1982) Farewell to North American megadriles. Megadrilogica 4:77

James SW (2011) Earthworms. In: Simberloff D, Rejmánek M (eds) Encyclopedia of Biological Invasions. University of California Press, Berkeley

Lee KE (1985) Earthworms: Their Ecology and Relationships with Soils and Land Use. Academic, Sydney

Malevich II (1956) To the earthworm fauna of the Far East. Proc VP Potemkin MSPI 61:439-449

Meshcheryakova EN, Berman DI (2014) The cold hardiness and geographic distribution of earthworms (Oligochaeta, Lumbricidae, Moniligastridae). Zool Zhurnal 93:53-64

Michaelsen W (1903) Die Geographische Verbreitung der Oligochaeten. Friedländer \& Sohn, Berlin

Michaelsen W (1929) Oligochaeten der Kamtschatka-Expedition. Yearbook of the AS USSR Zoological Museum 30(2):315-329

Perel TS (1979) Range and Regularities in the Distribution of Earthworms of the USSR Fauna. Nauka, Moscow

Pérez-Losada M, Eiroa J, Mato S, Domínguez J (2005) Phylogenetic species delimitation of the earthworms Eisenia fetida (Savigny, 1826) and Eisenia andrei Bouché, 1972 (Oligochaeta, Lumbricidae) based on mitochondrial and nuclear DNA sequences. Pedobiologia 49(4):317-324

Porco D, Decaëns T, Deharveng L, James SW, Skarzynski D, Erséus C, Butt KR, Richard B, Hebert PDN (2012) Biological invasions in soil: DNA barcoding as a monitoring tool in a multiple taxa survey targeting European earthworms and springtails in North America. Biol Inv 15:899-910

Ratnasingham S, Hebert PDN (2007) BOLD: the barcode of life data system. Mol Ecol Notes 7:355-364, www.barcodinglife.org

Rota E, Erséus C (1997) First record of Dendrobaena attemsi (Michaelsen) (Oligochaeta, Lumbricidae) in Scandinavia, with a critical review of its morphological variation, taxonomic relationships and geographical range. Ann Zool Fenn 34:89-104

Scheu S, Parkinson D (1994) Effects of earthworms on nutrient dynamics, carbon turnover and microorganisms in soils from cool temperate forests of the Canadian Rocky Mountains-laboratory studies. Appl Soil Ecol 1:113-125

Shekhovtsov SV, Golovanova EV, Peltek SE (2013) Cryptic diversity within the Nordenskiold's earthworm, Eisenia nordenskioldi subsp. nordenskioldi (Lumbricidae, Annelida). Eur J Soil Biol 58:13-18

Sokolskaya NL (1972) New data on the fauna of aquatic Oligochaeta from Kamchatka. Proc State Zool Museum 12:74-90

Sokolskaya NL (1983) Freshwater Oligochaeta of Kamchatka and the Koryak upland. Proc MSU Zool Museum 20:22-119

Tiunov AV, Hale CM, Holdsworth HM, Vsevolodova-Perel TS (2006) Invasion patterns of Lumbricidae into the previously earthworm-free areas of northeastern Europe and the western Great Lakes region of North America. Biol Inv 8:1223-1234

Vsevolodova-Perel TS (1997) The Earthworms of the Fauna of Russia. Nauka, Moscow
Vsevolodova-Perel TS, Bulatova NS (2008) Polyploid races of earthworms (Lumbricidae, Oligochaeta) in the East European plain and Siberia. Biol Bull 35(4):385-388

Vsevolodova-Perel TS, Leirikh AN (2014) Distribution and ecology of the earthworm Eisenia nordenskioldi pallida (Oligochaeta, Lumbricidae) dominant in Southern Siberia and the Russian Far East. Zool Zhurnal 93:45-52

doi:10.1186/s40555-014-0052-0

Cite this article as: Shekhovtsov et al: Invasive lumbricid earthworms of Kamchatka (Oligochaeta). Zoological Studies 2014 53:52.

\section{Submit your manuscript to a SpringerOpen ${ }^{\circ}$ journal and benefit from:}

- Convenient online submission

- Rigorous peer review

- Immediate publication on acceptance

- Open access: articles freely available online

- High visibility within the field

- Retaining the copyright to your article

Submit your next manuscript at $\gg$ springeropen.com 